\title{
Mass Production of Bananas and Plantains (Musa spp.) Plantlets through in vitro Tissue Culture Partway: A Review
}

\author{
Eustache T. A. E. Agbadje, Arnaud Agbidinoukoun, Martine Zandjanakou-Tachin, Gilles T. H. Cacaï \\ and Corneille Ahanhanzo
}

\section{ABSTRACT}

Bananas and plantains are among the most important food crops in Central and West Africa. Their plantation is lead to many problems. In the recent decades, biotechnology tools using in vitro culture technics are used for the mass and free disease plantlets production in order to increase the bananas production and the yield. The main way of in vitro tissue culture at this end is the direct organogenesis i.e., the ability of plant tissues to form various organs de novo by shoots or roots induction to differentiate from a cell or cell clusters. This review aims to summarize the main results obtained in the organogenesis of bananas and plantains (Musa spp.) under in vitro conditions and to identify the challenges during the process. The research articles used in this review show that micropropagation is a reliable alternative to conventional production system of bananas and plantains planting material. However, the use of the in vitro micropropagation for bananas and plantains entails choosing the optimal explant type and size according to objectives. Benzylaminopurine remains the preferred cytokinin for in vitro banana and plantain shoot proliferation, while the use of thidiazuron appears to be more and more common. Whichever cytokinin used, the optimal cytokinin concentration for shoot proliferation is genotype dependent. This review also focuses on the causes and control measures of the two major banana and plantain micropropagation constraints: lethal tissues browning/darkening and microbial contaminations. It showed that applying the suitable and available control measure, according to the evolution of culture, is necessary. All this available information on the in vitro conditions makes banana and plantain cultivars in vitro organogenesis possible.

Keywords: explant asepsis maintenance, growth regulators, lethal browning control, microbial contamination, Musa spp.

\section{INTRODUCTION}

Bananas and plantains (Musa species) are among the five major food commodities in the developing world. In banana and plantain, the difficulty to obtain large number of uniform disease free plants by the conventional propagation of techniques is one of the major limiting factors in increasing
Published Online: August 15, 2021

ISSN: $2684-5199$

DOI: $10.24018 /$ ejbio.2021.2.4.229

Eustache T. A. E. Agbadje *

Central Laboratory of Plant Biotechnology and Plant Improvement, Department of Genetics and Biotechnology, Faculty of Sciences and Techniques, University of AbomeyCalavi, Republic of Benin.

(e-mail: eustagbadje01@yahoo.fr) Arnaud Agbidinoukoun

Central Laboratory of Plant Biotechnology and Plant Improvement, Department of Genetics and Biotechnology, Faculty of Sciences and Techniques, University of AbomeyCalavi, Republic of Benin.

(e-mail: arnaudag2002@yahoo.fr)

Martine Zandjanakou-Tachin

School of Horticulture and Green Space Management (EHAEV), National University of Agriculture (UNA), Republic of Benin.

(e-mail: mtachin@yahoo.com)

Gilles T. H. Cacaï

Central Laboratory of Plant Biotechnology and Plant Improvement, Department of Genetics and Biotechnology, Faculty of Sciences and Techniques, University of AbomeyCalavi, Republic of Benin.

(e-mail: cagath@yahoo.fr)

Corneille Ahanhanzo

Central Laboratory of Plant Biotechnology and Plant Improvement, Department of Genetics and Biotechnology, Faculty of Sciences and Techniques, University of AbomeyCalavi, Republic of Benin.

(e-mail: Corneillea@yahoo.com)

*Corresponding Author

productivity. Tissue culture technology enable the rapid production of a large scale of uniform disease free plants from a single plant. Micropropagation of banana and plantain began in the mid-1970s. Today, it is well established and commonly used by commercial firms for industrial production of healthy planting material. Direct organogenesis, multiplication, and in vitro regeneration of plantlets from meristems or apices without callus induction, 
remains the pathway most used by commercial firms for the banana in vitro propagation. This pathway offers the potential to produce a large number of homogeneous and genetically identic plants [1]. Much research has been devoted to the organogenesis of bananas and plantains for more than four decades and new studies continue to be published. This review focuses on distinguishing between what already belongs to research achievements in the domain and production challenges. The aspects discussed in this review will give the state-of-the-art with respect to the type and size of the explant, its surface sterilization, the role of exogenous plant growth regulation, the browning due to oxidation of phenolic compounds and the contamination from pathogens such as endogenous bacteria.

\section{INFLUENCES OF THE TYPE AND SIZE OF EXPLANT}

For direct organogenesis of bananas and plantains, all parts of the plant containing a meristem are potentially suitable as initial explant. Therefore, buds from the main pseudo stem, its suckers, peepers or male inflorescence apices and immature male flowers are used as explants [2]. The influences of the type of explant, its size and the method of its sterilization are discussed in this section.

The organ used as explants can be classified into two types: stem buds and floral buds. Stem buds are the most preferred for in vitro tissues culture of bananas and plantains. This includes apical and axillary buds of young suckers as well as the lateral buds of the parental pseudo stem. They are easy to handle and damage to the parent plant during their removal is limited, when sampled from suckers [3]. Shoot tip from young sucker is the mostly used explant [4]. It promotes rapid multiplication and possible sanitation of plant material. It is highly protected by the superposition of leaf sheaths, which facilitates its survival during disinfection and during culture [5]. However, it allows only one explant per sucker [6], which can be a handicap if the number of suckers to be taken in the field is not sufficient to satisfy the important needs of vitroplants [7]. Little work has been published on axillary buds of suckers. However, their use allows to increase the number of initial explants per sucker. Three to four axillary buds can be removed from each sucker against a single apical bud [7]. In vitro proliferation of the axillary bud occurs earlier than shoot tip [8], but the survival rate after induction is low as compared to shoot tip [7]. This can be partly explained by the report of a poorer endogenous auxin of the axillary buds compared to the apical one; as there is an endogenous auxin gradient that decreases from the apex to the periphery [9]. For our understanding this theoretical difference in endogenous hormone content between axillary and apical buds could induce many differences in the response of the two types of explants during their culture. Hence, the addition of auxin to the initiation medium should be tailored to axillary buds to improve their survival rate. Studies are needed to confirm this hypothesis. The stem explants have the disadvantage of being more exposed to telluric microorganism contamination. In particular, the activities of the endogenous bacteria of these explants appear to be one major constraint of the micropropagation of banana and plantain [10].

The second type of explants are male inflorescence apex, axillary young flower buds, and terminal floral apex. In
French banana, terminal inflorescence apices and young flower buds in bract axils are capable of regenerating plantlets in vitro, similar to the shoot-tip culture technique [11]. It is the case in false horn-like plantains, which do not have a terminal apex and terminate with a floral structure [12]. The terminal floral apex and the axillary flower buds show morphogenic plasticity in their embryonic stage and can be induced to revert to vegetative meristems, multiplying in vitro and consisting a good starting material for micropropagation [2]. The apices can be used whole as a single explant [13] or split longitudinally into four to six parts [14], [15] while immature male flowers are used as a whole for explants. The use of this type of explant offers the opportunity to select in situ, a male bud from a bunch showing elite or highly desirable characteristics such as a large number of hands and fruits [1]. It is also an alternative in any cases where suckers were not available [14]. Moreover, since it is mostly not contaminated by telluric microorganisms, floral explants allow to reduce contamination rate during micropropagation, as compared to soil grown suckers [16]. Despite its potential, the proliferation rate of floral explants remains lower compared to stem explants [17].

According to the size of the explant, several reports revealed that the use of various sizes depends on the purpose of the culture. Ended, for the possible eradication of any bacterium and any virus, the meristematic dome surrounded by one or two primordia is used for the culture [18]. While for just propagation, the size of the explant generally varies between 2 and $5 \mathrm{~mm}$, up to $10 \mathrm{~mm}$ or even more [19], [20]. Meristem dome culture leads to slower regrowth and high mortality [21] following rapid explant dehydration, which is not the case for large explants. On the other hand, large explants can have lateral buds that provide shoots for multiplication. But the risk of loss by infection and blackening is higher, leading to final survival rate even lower than when meristem culture is used [4]. Hence, optimal size must be taken into account for both survival and proliferation optimal rate.

\section{EXPLANTS SURFACE STERILIZATION PRIOR IN VITRO Culture of BANANA AND Plantain}

A critical aspect for the in vitro culture process is the maintenance of asepsis [21], [22]. It is partly obtained by disinfecting the surface of the explants. Disinfection requirements depend on the type of explant. Explants from inflorescence or flowers are potentially less contaminated with telluric microorganisms. Therefore, a short rinse with ethanol $\left(70^{\circ}\right)$ can be sufficient for their disinfection [17], [14]. On the other hand, stem explants more exposed to telluric microorganisms require the use of more effective disinfectants to successfully carry out their surface sterilization. Disinfectants commonly used in this context are sodium hypochlorite, calcium chloride, mercuric chloride, and ethanol.

Calcium chloride is used at a concentration of $1.5 \%$ [23][25], whereas mercuric chloride is often used at a concentration of $0.1 \%$ [26], [27]. In general, sodium hypochlorite $(\mathrm{NaOCl})$ is used at a concentration ranging from $0.25 \%$ to $1 \%$ [5], [4], [28]. This disinfectant has proven very effective effect against all kinds of contaminants [29]. At a 
concentration of $1 \%$, sodium hypochlorite would be a better disinfectant than the mercuric chloride used at a concentration of $0.1 \%$ for 5 minutes [3]. In the absence of a laboratory $\mathrm{NaOCl}$ solution, commercial bleach is equally effective [30].

The chloride solutions are used in combination with a wetting agent (Tween 20, Tween 80 at a rate of one drop per $50 \mathrm{ml}$ of solution) or liquid soap to improve the action of the product [31]. The duration of immersion of the explant in the solution varies from 6 to 30 min according to the authors [25], [28]. Generally, immersion in the chloride solution is preceded by rinsing (15 seconds to $2 \mathrm{~min}$ ) in a solution of ethanol $\left(70^{\circ}\right.$ to $\left.96^{\circ}\right)$. Some authors recommended double disinfection: firstly, of large blocks of tissue that contains the meristem (about $4 \times 2 \mathrm{~cm}$ ) followed by another of a small block of $2 \times 1 \mathrm{~cm}$ [5]. This double disinfection allowed to reduce the contamination rate during the culture according to certain works [32].

\section{Microbial CONTAMINATION CONTROL DURING IN VITRO CULTURE OF BANANA AND PLANTAIN}

Microbial contamination is one of the major challenges of plant micropropagation [87]. The main microbial agents that develop in plant tissues culture are bacteria and fungi. Pseudomonas syringae, Bacillus licheniformis, Bacillus subtilis, Cornebacterium sp. and Erwinia spp. have been reported as the primary bacterial contaminants in plant tissue cultures [88], while Alterneria tenius, Aspergillus niger, Aspergillus fumigatus and Fusarium culmorum are the most commonly observed fungal contaminants [88], [89]. These organisms cause significant losses at initiation and during subcultures, with each subculture contributing 5 to $15 \%$ of losses [90]. In bananas and plantains, the overall losses caused by microbial contamination are estimated at $40-60 \%$, despite the use of reliable aseptic procedures [91]. Thus, a large number of explants are lost during culture due to microbial contamination [10].

Microbial contaminations are favored by in vitro culture conditions that induce a degree of stress and thus predispose the biological material to direct infection, even by microbes that normally are not pathogenic to it [92]. The culture media on which the plant tissue is grown is also a source of nutrients favorable for microbial growth, both the original constituents of the medium and the exudates of the plant cells. Thus, pathogenic, endophytic, epiphytic, or accidental contaminants can all develop, compete with plant tissues for nutrients, and interfere with their growth [93]. In addition, some of these contaminants produce phytotoxins that induce tissue necrosis, inhibit shoot proliferation and rooting. For example, Aspergillus niger and A. flavus have been reported to produce poisons such as oxalate and aflatoxin [94].

The major cause of microbial contamination that occurs during tissue culture process is imperfect sterilization of the explants, culture medium, work instruments, and operator's hands [90]. Generally, sterilization of the explant removes most epiphyte contaminants but not endogenous contaminants [10].

Endophytic bacteria are known to colonize intercellular spaces in various plants, with roots as the main entry point and niche [95]. In bananas, these endophytic bacteria also colonize intracellular spaces, including cytoplasm and the confined peri-space between the cell wall and the plasma membrane with a large number of organisms in both niches [96], [97]. It is recognized that all plants harbor endophytic bacteria, which are essentially harmless to the host, with a smaller population than pathogens [98]. During in vitro tissue culture, these endogenous bacteria escape into the nutrient medium, and grow in colonies large enough to compromise the culture [99]. They are therefore potential contaminants and modifiers to the growth of plant material in culture [100]. Work has shown three groups of endophytic bacteria associated with banana cv. Great Dwarf. While endophytes in the first group are easily cultivable and develop obvious colonies on Murashige and Skoog (MS) basal medium, those in the second and third groups first appear to survive in a viable but non-culturable state and then exhibit progressive "activation" of the cultivable form as the in vitro culture continues [101], [87]. This could partly justify the appearance of contaminations on material that has already undergone several subcultures without contamination.

\section{A. Control of the Activity of Endogenous Bacteria}

Contaminant control is provided by adding a specific dose of an antibiotic or a specific fungicide to the culture medium [91]. These products can also be used in pretreatment solution of explants before their introduction in vitro [10]. Hence, gentamicin, rifampicin or chloramphenicol added to the culture medium at a dose of $150 \mathrm{mg} / 1$ [91], cefotaxime at 500 ppm [102] have been revealed to be effective against the endogenous bacteria of the banana. By soaking the explants for $100 \mathrm{~min}$ in a gentamicin solution at $160 \mathrm{mg} / \mathrm{l}$ prior to in vitro introduction, $100 \%$ contamination-free cultures have been obtained [10]. Sometimes the combination of several antibiotics is needed to fight infections. But these antibiotic products are often bypassed by bacteria that become resistant [99]. They can also interfere with the growth of the explant. Other researchers have used antiseptic substances to control microbial contaminations in vitro. Banana-free cultures has been obtained by adding nanoparticles of $\mathrm{Zn}$ and $\mathrm{ZnO}$ to the culture medium, without any negative effect on regeneration [92]. The Application of systemic fungicides prior to plant material removal may also help to suppress these contamination [103]. Finally, the sampling of the suckers followed by the initiation of the explants during the dry season rather than in the rainy season on the one hand, the reduction of the content of the culture medium in sugar on the other hand are all effective measures of reducing or elimination microbial contaminations during banana and plantain tissues culture [22].

\section{INFLUENCE OF GROWTH REGULATORS ON BANANA AND PLANTAIN MICROPROPAGATION}

In plant cells, tissues or organs culture, growth regulators are crucial components of culture media as they influence the cell development pathway [33]. Cytokinins and auxins have important roles. Auxins are involved in root development while cytokinins favor shoot formation and bud regrowth. The combination of these growth regulators is necessary for in vitro culture media, and the ratio auxin/cytokinin needs to be considered to successfully modify the growth pattern of 
the plant material during the culture [34].

Firstly, cytokinins are plant growth regulators that control plant growth and development processes, such as cell division, elongation, and differentiation, seed dormancy and germination, leaf expansion and senescence, lateral buds growth and de novo bud formation, chloroplast and aerial organ development, morphogenesis [35], [36]. At high concentrations ( 1 to $10 \mathrm{mg} / 1)$, they can induce the formation of adventitious buds, but root formation is inhibited [37].

The natural cytokinins are derivatives of adenine, mainly zeatin but also isopentyladenine, kinetin, benzylaminopurine [38]; some of its derivatives that are also topolins [39]. Many phenylurea derivatives exhibit cytokinin activity in biological experiments but are not known as natural cytokinins. One of them is thidiazuron, a highly stable compound [40] and widely used now as a plant growth regulator.

For banana and plantain in vitro tissues culture, the mostly used constituent of culture medium for bud formation is clearly cytokinin [2]. Apart from the genotype, the rate of proliferation is influenced by the type of cytokinin and its concentration [41]. Benzylaminopurine is the most commonly preferred cytokinin [42], [43]. It is reported to be more effective on Musa spp. in vitro organogenesis than kinetin, isopentyladenine and zeatin [44]. Each cultivar appears to be reactive to an optimal concentration of benzylaminopurine, beyond which the rate of proliferation cannot be increased and may even decrease. Concerning the stem meristematic explants, the concentration of $22.2 \mu \mathrm{M}$ was indicated by several studies as optimal for the proliferation of most banana and plantain cultivars [42], [41], [45], [46]. Though, other values have been reported in other studies (Table I). Regeneration of male flowers and their in vitro multiplication are also influenced by cytokinin concentration [15]. Several concentrations of benzylaminopurine were also reported as indicated in Table I.

Despite its advantages, the use of benzylaminopurine has some drawbacks. At high doses, BAP inhibits shoot multiplication and elongation [47], [48], increases exudation of phenolic compounds [49] and favors the appearance of abnormal forms [50]. The toxicity of benzylaminopurine appears to be higher than other cytokinins. The use of benzylaminopurine in the culture medium needs to be carefully regulated to optimize proliferation and produce normal plantlets [33].

Thidiazuron, urea-based cytokinin, can allow better multiplication rate than benzylaminopurine [51]. The doses used for optimal proliferation are generally low as compared to those required for BAP [52], [53]. An exception was reported (benzylaminopurine favoring better organogenesis than thidiazuron) in proliferation for the cultivar 'Kluai Hin' of Musa balbisiana [54]. The doses of thidiazuron used vary from 0.05 to $2.5 \mu \mathrm{M}$ and sometimes slightly more according to the cultivars [52], [40], [55]. The use of thidiazuron in banana micropropagation could be more economical than adenine-based cytokinins [56]. But high concentrations of thidiazuron can induce appearance of abnormal forms [57]. Thidiazuron at $0.2 \mathrm{mg} / \mathrm{l}$ induces more abnormal forms than benzylaminopurine at $5 \mathrm{mg} / \mathrm{l}$ [58].

The optimal concentration of a given cytokinin for proliferation depend on the genotype. Thus, for each new genotype to be introduced in vitro, tests are needed to determine the optimal concentration for proliferation. Auxins are phytohormones that control various plant responses such as cell division and elongation, differentiation, root formation, and apical dominance [36]. Natural endogenous auxin is indole-3-acetic acid (AIA). The most widely used synthetic auxins in plants tissue culture are indole-3-butyric acid (AIB), naphthalene acetic acid (NAA) and 2,4dichlorophenoxyacetic acid (2,4-D) [59].

For direct organogenesis of banana and plantain, auxins are mainly involved in root formation. The most commonly used are AIB, AIA and NAA at doses generally ranging from 0.5 $\mathrm{mg} / \mathrm{l}$ to $2 \mathrm{mg} / \mathrm{l}$ [60]-[63]. But it has been reported that at high doses auxin has a negative influence on root length.

Auxins are sometimes used in combination with a cytokinin to ensure bud proliferation. The interaction between different cytokinins and NAA or AIA has been used to improve the proliferation rate [64], [19], [65]. However, for 'Basrai' (Musa spp., AAA group), AIA (1 mg/l and $2 \mathrm{mg} / \mathrm{l})$ combined with multiple doses of BAP $(0 \mathrm{mg} / \mathrm{l}$ to $8 \mathrm{mg} / \mathrm{l}$ ) did not affect shoot proliferation [66]. This could be related to the dose of endogenous auxin which itself would depend on the genotype.

TABLE I: VARIATION OF BENZYLAMINOPURINE CONCENTRATION DURING PROLIFERATION OF VARIOUS CULTIVARS

\begin{tabular}{cccc}
\hline \hline \multirow{2}{*}{ Explants } & $\begin{array}{c}\text { BAP } \\
\text { Concentrations } \\
(\mu \mathrm{M})\end{array}$ & Cultivars & References \\
\hline \multirow{5}{*}{ Stem bud } & 5.00 & FHIA-17 & {$[29]$} \\
& 8.89 & BARI-1 & {$[104]$} \\
& 13.32 & FIHA- 21, & {$[105]$} \\
& 17.78 & PITA-3 & {$[27]$} \\
& 20.00 & Amritasagar & {$[64],[82]$} \\
Floral & 22.20 & Oniaba, & {$[1],[41]$} \\
bud & 31.08 & Red banana & {$[16]$} \\
& 35.52 & Berangan & {$[14]$} \\
& 44.40 & Berangan, & {$[106]$} \\
\hline \hline
\end{tabular}

\section{BROWNING / BLACKENING OF SHOOTS NECROSIS MANAGEMENT}

Potential problems with banana and plantain in tissue culture include browning/darkening of the medium and excised faces of explants during the initiation and subcultures phases [2], browning of young leaf, shoot necrosis, plantlets death during the proliferation, and rooting phases [67]. These phenomena are mainly due to the oxidation of phenolic compounds [68] but probably also to the depletion of the medium in mineral nutrients or in growth regulators or both [69].

\section{A. Phenolic Compounds Oxidation during Banana and Plantain Tissue Culture}

Banana tissues are known to contain large amount of latex and phenolic compounds [70]. They are secondary metabolites present in large quantities in plants. They regulate the catabolism of indole acetic acid (AIA) [71] and thus control plant growth, cell differentiation and organogenesis. The production of phenols is stimulated when tissues are injured, leading to the activation of certain oxidative enzymes such as polyphenol oxidase (PPO). Apart from PPO, other 
oxidative enzymes such as peroxidase (POD) and phenylalanine ammonia lyase (PAL), also contribute to wound induced browning. These enzymes were considered as marker of oxidative metabolism. In most plants PODs were heme-containing enzymes that catalyze the conversion of $\mathrm{H} 2 \mathrm{O} 2$ to water using phenolic compounds as hydrogen donors. PAL as a branch point enzyme in phenylpropanoid pathway has a profound impact on progress of browning/necrosis of plant tissues. In addition, POD and PPO may act synergistically in enzymatic browning, because PPO may promote POD activity by generating $\mathrm{H}_{2} \mathrm{O}_{2}$ from the oxidation of phenolic compounds [72]. Oxidation of phenolic compound is a natural defense process that induce the formation of quinones and highly reactive forms of oxygen [70]. These oxidation products are toxic to infectious pathogens and pests. They may also undergo non-enzymatic auto-polymerization or covalent hetero-condensation with proteins and carbohydrates to produce colored compounds [73]. The colored compounds produced generally constitute a physical barrier against biotic and abiotic stresses. During in vitro tissue culture, the phenols are released into the culture medium by the wounded ends of the explant and accumulate therein. The products of their oxidation gradually penetrate the tissues and repress the enzymatic activities. As a result, they have very toxic effect on the plant tissues [74]. In addition, the colored compounds they produce surround the explant and form a barrier that prevents the absorption of nutrients [75]. Finally, the oxidation of phenolic compounds and other exudates during plant tissues culture negatively influences explant survival, plantlets proliferation and growth [76], [74].

\section{B. Control of the Oxidation of Phenolic Compounds}

There are several ways to prevent or reduce the adverse effects of the oxidation of phenolic compounds during bananas and plantains tissue culture. These include the addition to the culture medium of an antioxidant [77], [75], [78] or adsorbents such as activated charcoal [79], [80], [63]; pretreatment of the explant by immersion in an antioxidant solution prior to introduction in vitro [81], [68]; increase in the concentration of the medium in calcium [67], [69]; increased frequency of subcultures and periodic culture in the dark [4], [70]; drying of the suckers under shade for several days before explants isolation [82], [83].

\section{Antioxidants}

Antioxidants inhibit the oxidation of labile substrates and protect the tissues. The main antioxidants used in plant tissue culture to control the oxidation of phenolic compounds are ascorbic acid, citric acid, and cysteine. They are used as pretreatment solution to prepare the explant before initiation or as component of the culture medium.

Ascorbic acid has been used by several authors to control tissue browning in vitro. The addition of ascorbic acid at doses ranging from $10 \mathrm{mg} / \mathrm{l}$ to $150 \mathrm{mg} / \mathrm{l}$ in the medium has been indicated to reduce the phenomenon of tissue darkening [4]. This large range of required concentrations may be due to the effect of the genotype [75]. As reported, for the cultivar Mzuzu of banana, high concentrations of ascorbic acid (100 and $200 \mathrm{mg} / \mathrm{l}$ ) added to the culture medium are effective in reducing tissue browning during 4 weeks of culture [68]. On the other hand, at low concentration $(50 \mathrm{mg} / \mathrm{l})$, the effectiveness of ascorbic acid does not exceed the first week of culture. Furthermore, the preparation of the explant by immersion for one hour in $1.2 \mathrm{~g} / \mathrm{l}$ solution of ascorbic acid was just as effective as the addition of $100 \mathrm{mg} / \mathrm{l}$ of this product to the culture medium [68]. In the proliferating or rooting phase, the addition of ascorbic acid to the culture medium, prevents lethal browning of plantlets as well as inhibits the oxidation process and restores plantlets already affected [77]. It is believed that the ascorbic acid absorbed by the plantlet migrates to the leaves in order to prevent the oxidation of phenolic compounds, making its presence in the culture medium to be beneficial to improvement of plantlets proliferation [77], [74]. It is recommended to add the ascorbic acid solution at the surface of the culture medium after autoclaving rather than adding it before, because it's affected by the heat. The addition of ascorbic acid to the culture medium prior to autoclaving may partially explain the ineffectiveness of the product in reducing browning observed in some cases [75], [77].

Citric acid is also effectively used to control tissue browning, darkening and death. Like ascorbic acid, citric acid can be added at a dose varying from 10 to $150 \mathrm{mg} / \mathrm{l}$ to the culture medium [4]. A $0.125 \%$ solution of a combination of citric acid and potassium citrate (4: $1 \mathrm{~m} / \mathrm{m}$ ratio) has been used successfully to treat explants such as banana flower apex [81] and shoot apices of plantain [84] prior to their introduction in vitro. The combination of citrate and citric acid functions as a chelating agent for the ions responsible for the activation of polyphenol oxidase.

The cysteine has been proposed at a concentration of 50 $\mathrm{mg} / \mathrm{l}$ to treat the explant for a few minutes before its introduction in vitro [4].

\section{Adsorbents}

Activated charcoal is the main adsorbent used for in vitro culture of banana and plantain. Activated charcoal is composed of carbon arranged in a quasi-graphitic form in small particles size. It has a fine network of pores with an extraordinarily large surface area on which many substances can be adsorbed. Activated charcoal is often used in plant tissue culture to enhance growth and cell development. Its main advantages are the adsorption of inhibitory substances in the culture medium, a drastic decrease in the phenolic oxidation or brown exudate accumulation, the alteration of medium $\mathrm{pH}$ to an optimum level for morphogenesis, the establishment of a darkened environment in medium and hence simulate soil conditions [79]. However, activated charcoal could also adsorb vitamins, cytokinins and auxins, thereby altering the concentrations of the components of the medium and subsequently influencing plant regeneration. Hence, the use of activated charcoal does not allow researchers to control the quantities of exogenous hormones that are free and really available for plant tissues [78]. During micropropagation of banana and plantain, activated charcoal is generally used to promote rooting at doses ranging from 1.0 to $2.5 \mathrm{~g} / 1$ [4], [17], [85], [86]. Activated charcoal alone at $1.5 \mathrm{~g} / \mathrm{l}$ or in combination with $150 \mathrm{mg} / \mathrm{l}$ of ascorbic acid or citric acid permitted to inhibit the oxidation of phenolic compounds and enhances plantlet growth in Grande Naine cultivar [63]. On the other hand, some authors indicated that adsorbents in general (exchange resin, anion exchange resin, 
polyvinylpyrrolidone and activated charcoal) are not effective in reducing the lethal browning of Formosana plantlets while ascorbic acid has been effective to solve the problem [77] These authors stated that the oxidation of phenolic compounds would occur within the leaves of plantlets, causing their browning and death. Thus, the adsorbents can help to control browning especially at the initiation where the phenolic compounds are released into the culture medium by the excised faces of the explant.

\section{E. Other Methods of Controlling Browning}

Rapid transfer of the explants to a fresh medium twice or thrice during establishment is the simplest and most effective method of protecting explants from the harmful effects of browning. During this period, the cut end of the explant becomes sealed up and the leaching of phenolic stop [70]. This also allow to avoid the invasion of tissues by the toxic products resulting from the oxidation of phenols. These subcultures can be performed every one to two weeks [4]. Keeping the fresh crops in complete darkness for a week can also help reducing the problem of browning by preventing or reducing the activity of enzymes involved in both phenol biosynthesis and oxidation [4], [70]. Drying the suckers under shade for a few days reduces the content of the material in phenolic and their exudation during establishment [82], [83].

\section{CONCLUSION}

The use of in vitro micropropagation for bananas and plantains entails choosing the optimal explant type and size according to objectives. The in vitro survival of the explant strongly depends on the measures taken to control the browning / darkening of tissues and microbial contamination. In particular, the control of the activities of endophytic bacteria remains a permanent challenge for the in vitro culture of banana and plantain. Benzylaminopurine remains the preferred cytokinin for in vitro banana and plantain shoot proliferation, while the use of thidiazuron appears to be more and more common. Whichever cytokinin used, the optimal cytokinin concentration for shoot proliferation is genotype dependent. Auxins are mainly involved in rhizogenesis but they are also used in combination with cytokinins to improve the proliferation rate. All this available information on the in vitro conditions makes banana and plantain cultivars in vitro organogenesis possible.

\section{ACKNOWLEDGMENT}

The authors thank Dr. Gueye Badara and Dr. David Montcho, respectively from the International Institute of Tropical Agriculture (IITA, Ibadan) and National University of Agriculture (UNA, Benin) for their contributions in the improvement of the manuscript quality.

\section{REFERENCES}

[1] Resmi, L., and Nair, A.S. (2007). Plantlet production from the male inflorescence tips of Musa acuminata cultivars from South India. Plant Cell Tissue Organ Cult. 2007; 88, 333-338.

[2] Vuylsteke, D. (1998). Shoot-tip culture for the propagation, conservation and distribution of Musa germplasm (IITA) 1998.
[3] Kishor, H., Abhijith, Y., and Manjunatha, N. (2017). Micropropagation of Native Cultivars of Banana-A Critical Review. Int. J. Pure App. Biosci. 2017; 5, 1559-1564.

[4] Strosse, H., Van den Houwe, I., and Panis, B. (2004). Banana cell and tissue culture-review. In Banana improvement cellular, molecular biology and induced mutations, S.M. Jain, and R. Swennen, eds. (Science Publishers, Inc), 2004; pp. 1-12.

[5] Teisson, C., and Côte, F.-X. (1997). Micropropagation of Musa species (bananas). In Biotechnology in Agriculture and Forestry 39 High-Tech and Micropropagation V, Y.P.S. Bajaj, ed. (Springer), 1997; pp. 103 126.

[6] Sandoval, J., and Müller, L.E. (1987). Influencia del tamaño de explante en la propagación in vitro de cuatro cultivares de Musa. Turrialba (IICA) 1987;42, 243-248.

[7] Youmbi, E., and Ngaha, D. (2004). Expression in vitro des capacités organogènes des bourgeons axillaires chez le bananier plantain (Musa spp.). Fruits 2004; 59, 241-248.

[8] Youmbi, E., Tchananyambeu, M., and Fonbah, C. (2014). In vitro Proliferation Ability of Axillary Buds in Musa spp. Agron. Afr. 2014;26, 1-7.

[9] Heller, R., Esnault, R., and Lance, C. (1995). Physiologie végétale. Tome 2. Développement (Masson) 1995.

[10] Habiba, U., Reza, S., Saha, M.L., Khan, M., and Hadiuzzaman, S. (2002). Endogenous bacterial contamination during in vitro culture of table banana: Identification and prevention. Plant Tissue Cult. 2002; 12, 117-124.

[11] Cronauer, S., and Krikorian, A. (1985). Aseptic multiplication of banana from excised floral apices. HortScience 1985; 20, 770-771.

[12] Cronauer-Mitra, S.S., and Krikorian, A. (1988). Determinate floral buds of plantain (Musa AAB) as a site of adventitious shoot formation. Ann Bot. 1988; 61, 507-512.

[13] Kumar, K.G., Krishna, V., Venkatesh, V., and Pradeep, K. (2011). High Frequency Regeneration of Plantlets from Immature Male Floral Explants of Musa paradisica cv. Puttabale-AB Genome. Plant Tissue Cult. Biotech. 2011; 21, 199-205.

[14] Darvari, F.M., Sariah, M., Puad, M., and Maziah, M. (2010). Micropropagation of some Malaysian banana and plantain (Musa spp.) cultivars using male flowers. Afr. J. Biotechnol. 2010; 9, 2360-2366.

[15] Mahadev, S.R., Kathithachalam, A., and Marimuthu, M. (2011). An efficient protocol for large-scale plantlet production from male floral meristems of Musa spp. cultivars Virupakshi and Sirumalai. In vitro Cell. Dev. Biol.-Plant 2011; 47, 611-617.

[16] Harirah, A.A., and Khalid, N. (2006). Direct regeneration and rapd assessment of male inflorescence derived plants of musa cuminata $\mathrm{cv}$. berangan. AsPac J. Mol. Biol. Biotechnol. 2006; 14, 11-17.

[17] Wirakarnain, S., Hossain, A., and Chandran, S. (2008). Plantlet production through development of competent multiple meristem cultures from male inflorescence of banana, Musa acuminta cv. "Pisang Mas" (AA). Am. J. Biochem. Biotechnol. 2008; 4, 325-328.

[18] Youssef, M., James, A., Mayo-Mosqueda, A., Ku-Cauich, J.R., Grijalva-Arango, R., and Escobedo-GM, R.M. (2010). Influence of genotype and age of explant source on the capacity for somatic embryogenesis of two Cavendish banana cultivars (Musa acuminata Colla, AAA). Afr. J. Biotechnol. 2010; 9, 2216-2223.

[19] Al-Amin, M., Karim, M., Amin, M., Rahman, S., and Mamun, A. (2009). In vitro micropropagation of banana. Bangladesh J. Agril. Res. 2009; 34, 645-659.

[20] Shankar, C.S., Balaji, P., and Sekar, D.S. (2014). Mass Propagation of Banana (Musa spp.) cv. Grand Naine through Direct Organogenesis by Benzyl Adenine Purine and Kinetin. J. Acad. Ind.Res. 2014; 3, 92-97.

[21] Lassois, L., Lepoivre, P., Swennen, R., van den Houwe, I., and Panis, B. (2013). Thermotherapy, chemotherapy, and meristem culture in banana. In Protocols for micropropagation of selected economicallyimportant horticultural plants, M. Lambardi, E. A. Ozudogru, S. M Jain, eds. (Springer), 2013; pp 419-433.

[22] Waman, A., Bohra, P., Sathyanarayana, B., Umesha, K., Mukunda, G., Ashok, T., and Gowda, B. (2015). Optimization of factors affecting in vitro establishment, ex vitro rooting and hardening for commercial scale multiplication of silk banana (Musa AAB). Erwerbs-Obstbau 2015; 57, 153-164.

[23] Banerjee, N.a.d.L.E. (1985). A tissue culture technique for rapid clonal propagation and storage under minimal growth conditions of Musa (Banana and plantain). Plant Cell Rep. 4, 351-354.

[24] Madhulatha, P., Anbalagan, M., Jayachandran, S., and Sakthivel, N. (2004). Influence of liquid pulse treatment with growth regulators on in vitro propagation of banana (Musa spp. AAA). Plant Cell Tissue Organ Cult. 2004; 76, 189-192.

[25] Kone, T., Kone, M., Kone, D., Kouakou, T.H., Traore, S., and Kouadio, Y. (2010). Effet de la photopériode et des vitamines sur la 
micropropagation du bananier plantain (Musa $\mathrm{AAB}$ ) à partir de rejets écailles de rang1. J. Appl. Biosci. 2010;26, 1675-1686.

[26] Kalimuthu, K., Saravanakumar, M., and Senthilkumar, R. (2007). In vitro micropropagation of Musa sapientum L. (Cavendish Dwarf). Afr. J. Biotechnol. 6, 1106-1109.

[27] Shiragi, M., Baque, M., and Nasiruddin, K. (2008). Eradication of Banana Bunchy Top Virus (BBTV) and Banana Mosaic Virus (BMV) from Infected Plant of Banana cv. Amritasagar through Meristem Culture. South Pac. Stud. 29, 17-41.

[28] Gandonou, G., Ahanhanzo, C., Agbangla, C., Agbidinoukoun, A., Doussoh, A., Cacai, G., and Dossoukpevi, R. (2012). Micropropagation in vitro de la variété locale «Aloga» du bananier plantain (Musa $x$ paradisiaca L.) au Bénin. Int. J. Biol. Chem. Sci. 2012; 6, 1102-1111.

[29] Kahia, J., Ndaruhutse, F., Waweru, B., Bonaventure, N., Mutaganda, A., Sallah, P.Y., Kariuki, N.P., and Asiimwe, T. (2015). In vitro propagation of two elite cooking banana cultivars-FHIA 17 and INJAGI. Int. J. Biotechnol. Mol. Biol. Res. 2015; 6, 40-47.

[30] Farzinebrahimi, R., Rashid, K., Taha, R.M., and Yaacob, J.S. (2013). Effective Sterilization Protocol for Micropropagation of Musa coccinea (Musa Spp). In International Conference on Agriculture and Biotechnology (IACSIT Press, Singapore) 2013.

[31] Jarret, R., Fisher, J., and Litz, R. (1985). Organ formation in Musa tissue cultures. J. Plant Physiol. 1985; 121, 123-130.

[32] Hamill, S., Sharrock, S., and Smith, M. (1993). Comparison of decontamination methods used in initiation of banana tissue cultures from field-collected suckers. Plant Cell Tissue Organ Cult. 1993; 33 , 343-346.

[33] Jafari, N., Othman, R.Y., and Khalid, N. (2011). Effect of benzylaminopurine (BAP) pulsing on in vitro shoot multiplication of Musa acuminata (banana) cv. Berangan. Afr. J. Biotechnol. 2011; 10 , 2446-2450.

[34] Dixon, R.A., and Gonzales, R.A. (1994). Plant cell culture: a practical approach (IRL press) 1994.

[35] Davies, P.J. (2010). The plant hormones: their nature, occurrence, and functions. In Plant hormones (Springer) 2010; pp. 1-15.

[36] Spíchal, L. (2012). Cytokinins-recent news and views of evolutionally old molecules. Funct. Plant. Biol. 39, 267-284.

[37] Gana, A. (2011). The role of synthetic growth hormones in crop multiplication and improvement. Afr. J. Biotechnol. 2011; 10, 1033010334.

[38] Ganapathi, T., Mohan, J., Suprasanna, P., Bapat, V., and Rao, P. (1995). A low-cost strategy for in vitro propagation of banana. Curr. Sci. 1995; 68, 646-650.

[39] Mok, M.C., Martin, R.C., Dobrev, P.I., Vanková, R., Ho, P.S., Yonekura-Sakakibara, K., Sakakibara, H., and Mok, D.W. (2005) Topolins and hydroxylated thidiazuron derivatives are substrates of cytokinin O-glucosyltransferase with position specificity related to receptor recognition. Plant Physiol. 2005; 137, 1057-1066.

[40] Mok, M., Mok, D., Armstrong, D., Shudo, K., Isogai, Y., and Okamoto, T. (1982). Cytokinin activity of N-phenyl-N'-1, 2, 3-thiadiazol-5ylurea (thidiazuron). Phytochemistry 1982;21, 1509-1511.

[41] Shirani, S., Mahdavi, F., and Maziah, M. (2009). Morphological abnormality among regenerated shoots of banana and plantain (Musa spp.) after in vitro multiplication with TDZ and BAP from excised shoottips. Afr. J. Biotechnol. 2009; 8, 5755-5761.

[42] Cronauer, S.S., and Krikorian, A. (1984). Multiplication of Musa from excised stem tips. Ann Bot. 1984; 53, 321-328.

[43] Buah, J. (2014). Suitability of Cassava Starch as a Gelling Agent for the in vitro Culture of Banana Plantlets. Am. J. Food Technol. 2014; 9 , 340-349.

[44] Rahman, S., Biswas, N., Hassan, M.M., Ahmed, M.G., Mamun, A., Islam, M.R., Moniruzzaman, M., and Haque, M.E. (2013) Micropropagation of banana (Musa sp.) cv. Agnishwar by in vitro shoot tip culture. Int. Res. J. Biotechnol. 2013; 4, 83-88.

[45] Yusnita, Y., Danial, E., and Hapsoro, D. (2015). In vitro shoot regeneration of Indonesian bananas (Musa spp.) cv. Ambon Kuning and Raja Bulu, plantlet acclimatization and field performance. Agrivita 2015; 37, 51-58.

[46] Khatun, F., Hoque, M., Huq, H., Adil, M., Ashraf-Uz-Zaman, K., and Rabin, M.H. (2017). Effect of BAP and IBA on in vitro Regeneration of Local Banana Variety of Sabri. Biotechnol. J. Int. 2017; 18, 1-10.

[47] Cruz-Rosero, N., Canchignia-Martínez, H., Morante-Carriel, J., NietoRodríguez, E., Cruz-Rosero, E., Cabrera-Casanova, D., IzquierdoOviedo, H., Disotuar, R., González, M.C., and González, S.J. (2016) In vitro propagation of the Fiorito banana cultivar (Musa acuminata AA). Biotecnol Apl. 2016; 33, 4201-4204.

[48] Karule, P., Dalvi, V., Kadu, A., Chaudhari, R., Subramaniam, V., and Patil, A. (2016). A commercial micropropagation protocol for virupakshi (AAB) banana via apical meristem. Afr. J. Biotechnol. 2016; 15, 401-407.
[49] Venkatachalam, L., Sreedhar, R., and Bhagyalakshmi, N. (2007). Micropropagation in banana using high levels of cytokinins does not involve any genetic changes as revealed by RAPD and ISSR markers. Plant Growth Regul. 2007; 51, 193-205.

[50] Bairu, M.W., Stirk, W.A., Doležal, K., and van Staden, J. (2008). The role of topolins in micropropagation and somaclonal variation of banana cultivars 'Williams' and 'Grand Naine' (Musa spp. AAA). Plant Cell Tissue Organ Cult. 2008; 95, 373-379.

[51] Makara, A., Rubaihayo, P., and Magambo, M. (2010). Carry-over effect of Thidiazuron on banana in vitro proliferation at different culture cycles and light incubation conditions. Afr. J. Biotechnol. 2010; 9, 3079-3085.

[52] Strosse, H., Andre, E., Sági, L., Swennen, R., and Panis, B. (2008) Adventitious shoot formation is not inherent to micropropagation of banana as it is in maize. Plant Cell Tissue Organ Cult. 2008; 95, 321332.

[53] Youmbi, E., Ella, B., and Tomekpe, K. (2006). Effect of thidiazuron on in vitro proliferation capacities of some banana (Musa spp.) cultivars with weak multiplication potential. Mediterr. Agric. Sci. 2006; 19, 255-259.

[54] Kanchanapoom, K., and Promsorn, N. (2012). Micropropagation and in vitro germplasm conservation of endangered Musa balbisiana 'Kluai Hin' (BBB group). Afr. J. Biotechnol. 2012; 11, 6464-6469.

[55] Daungban, S., Pumisutapon, P., Topoonyanont, N., and Poonnoy, P. (2017). Effects of Explants Division by Cutting, Concentrations of TDZ and Number of Sub-culture Cycles on Propagation of 'Kluai Hom Thong'Banana in a Temporary Immersion Bioreactor System. Thai J. Sci. Technol. 2017; 6, 89-99.

[56] Arinaitwe, G., Rubaihayo, P., and Magambo, M. (2000). Proliferation rate effects of cytokinins on banana (Musa spp.) cultivars. Sci. Hortic. 2000; 86, 13-21.

[57] Farahani, F., Aminpoor, H., Sheidai, M., Noormohammadi, Z., and Mazinani, M. (2008). An improved system for in vitro propagation of banana (Musa acuminata L.) cultivars. Asian J. Plant Sci. 2008; 7, 116 118 .

[58] Manjula, R., Jholgiker, P., Subbaiah, K.V., Prabhuling, G., Swamy, G., and Kumar, Y.L. (2014). Morphological abnormality among hardened shoots of banana cv. Rajapuri (AAB) after in vitro multiplication with TDZ and BAP from excised shoot tips. Int. J. Agri. Environ.Biotechnol. 2014; 7, 465-470.

[59] Gutiérrez-Mora, A., González-Gutiérrez, A.G., Rodríguez-Garay, B., Ascencio-Cabral, A., and Li-Wei, L. (2012). Plant somatic embryogenesis: some useful considerations. In Embryogenesis, Dr. Ken-Ichi Sato ed. (InTech), pp. 2012; 229-248.

[60] Roy, O.S., Bantawa, P., Ghosh, S.K., da Silva, J.A.T., Ghosh, P.D., and Mondal, T.K. (2010). Micropropagation and field performance of 'Malbhog' (Musa paradisiaca, AAB group): a popular banana cultivar with high keeping quality of north east India. Tree for. Sci. Biotechnol. 2010; 4, 52-58.

[61] Hussein, N. (2012). Effects of nutrient media constituents on growth and development of banana (Musa spp.) shoot tips cultured in vitro. Afr. J. Biotechnol. 2012; 11, 9001-9006.

[62] Ngomuo, M., Mneney, E., and Ndakidemi, P. (2013). The effects of auxins and cytokinin on growth and development of (Musa sp.) var. "Yangambi" explants in tissue culture. Am. J. Plant Sci. 2013; 4, 2174 2180.

[63] Safwat, G., Abdul-Rahman, F., and El Sharbasy, S. (2016). The effect of some antioxidants on blackening and growth of in vitro culture of banana (Musa spp. cv. Grand naine). Egypt. J. Genet. Cytol. 2016; 44, 47-59.

[64] Gübbük, H., and Pekmezci, M. (2004). In vitro propagation of some new banana types (Musa spp.). Turk. J. Agric. For. 2004; 28, 355-361.

[65] Bandita, D., and Bikram, P. (2017). Effects of plant growth hormones on shoot proliferation of Musa paradisiaca cv. Bantal. Int. J. Plant Sci. 2017; 12, 135-138

[66] Muhammad, A., Rashid, H., Hussain, I., and Naqvi, S.S. (2007). Proliferation-rate effects of BAP and kinetin on banana (Musa spp. AAA Group) 'Basrai'. HortScience 2007; 42, 1253-1255.

[67] Martin, K.P., Zhang, C.-L., Slater, A., and Madassery, J. (2007). Control of shoot necrosis and plant death during micro-propagation of banana and plantains (Musa spp.). Plant Cell Tissue Organ Cult. 2007; $88,51-59$.

[68] Ngomuo, M., Mneney, E., and Ndakidemi, P. (2014a). Control of lethal browning by using ascorbic acid on shoot tip cultures of a local Musa spp. (Banana) cv. Mzuzu in Tanzania. Afr. J. Biotechnol. 2014a; 13, 1721-1725.

[69] Bairu, M.W., Stirk, W.A., and Van Staden, J. (2009). Factors contributing to in vitro shoot-tip necrosis and their physiological interactions. Plant Cell Tissue Organ Cult. 2009; 98, 239-248. 
[70] Ahmad, I., Hussain, T., Ashraf, I., Nafees, M., Maryam, R.M., and Iqbal, M. (2013). Lethal effects of secondary metabolites on plant tissue culture. Am. Eurasian J. Agric. Environ. Sci. 2013; 13, 539-547.

[71] Ozyigit, I.I. (2008). Phenolic changes during in vitro organogenesis of cotton (Gossypium hirsutum L.) shoot tips. Afr. J. Biotechnol. 2008; 7, $1145-1150$.

[72] Tabiyeh, D.T., Bernard, F., Shacker, H., 2006. Investigation of glutathione, salicylic acid and GA3 on browning in Pistacia vera shoot tips cultures. Acta Hortic. 2006; 726, 201-204.

[73] Krishna, H., Sairam, R., Singh, S., Patel, V., Sharma, R., Grover, M., Nain, L., and Sachdev, A. (2008). Mango explant browning: Effect of ontogenic age, mycorrhization and pre-treatments. Sci. Hortic. 2008; $118,132-138$.

[74] Ssekiwoko, F., Talengera, D., Kiggundu, A., Namutebi, M., Karamura, E., and Kunert, K. (2014). In-vitro proliferation of Musa balbisiana improves with increased vitamin concentration and dark culturing. J. appl. biol. biotechnol. 2014; 2, 001-007.

[75] Chikezie, U. (2012). Effect of ascorbic acid on blackening and sprouting of Musa spp shoot tips. ISABB. J. Biotech. Bioinform. 2012 2, 11-17.

[76] Ndakidemi, C.F., Mneney, E., and Ndakidemi, P.A. (2014). Effects of ascorbic acid in controlling lethal browning in in vitro culture of Brahylaena huillensis using nodal segments. Am. J. Plant Sci. 2014; 5, 187-191.

[77] Ko, W., Su, C., Chen, C., and Chao, C. (2009). Control of lethal browning of tissue culture plantlets of Cavendish banana cv. Formosana with ascorbic acid. Plant Cell Tissue Organ Cult. 2009; 96 , 137-141.

[78] Ngomuo, M., Mneney, E., and Ndakidemi, P.A. (2014b). The in vitro propagation techniques for producing banana using shoot tip cultures. Am. J. Plant Sci. 2014b; 5, 1614-1622.

[79] North, J., Ndakidemi, P., and Laubscher, C. (2012). Effects of antioxidants, plant growth regulators and wounding on phenolic compound excretion during micropropagation of Strelitzia reginae. Int. J. Phys. Sci.2012; 7, 638-646.

[80] Thomas, T.D. (2008). The role of activated charcoal in plant tissue culture. Biotechnol Adv. 2008; 26, 618-631.

[81] Titov, S., Bhowmik, S.K., Mandal, A., Alam, M.S., and Uddin, S.N. (2006). Control of phenolic compound secretion and effect of growth regulators for organ formation from Musa spp. cv. Kanthali floral bud explants. Am. J. Biochem. Biotechnol. 2006; 2, 97-104.

[82] Buah, J., Danso, E., Taah, K., Abole, E., Bediako, E., Asiedu, J., and Baidoo, R. (2010). The effects of different concentrations cytokinins on the in vitro multiplication of plantain (Musa spp.). Biotechnology 2010; 9, 343-347.

[83] Agbadje, E.T.A.-E.F., Agbidinoukoun, A., Zandjanakou-Tachin, M., Cacaï, G.T.H., Houedjissin, S.S., and Ahanhanzo, C. (2017). Effect of drying plantain (Musa spp.) suckers prior to in vitro culture on reduction of lethal browning. Int. J. Agric. Pol. Res. 2017; 5, 192-200

[84] Onuoha, C., Eze, C., Unamba, C., and UGOCHUKWU, C. (2011). In vitro prevention of browning in plantain culture. Rom. J. Biol. - plant biol. 2011; 56, 123-130.

[85] Singh, H., Uma, S., Selvarajan, R., and Karihaloo, J. (2011). Micropropagation for production of quality banana planting material in Asia-Pacific. Asia-Pacific Consortium on Agricultural Biotechnology (APCoAB) Asia-Pacific Association of Agricultural Research Institutions (APAARI) (New Delhi, India 2011.

[86] Husin, N., Jalil, M., Othman, R.Y., and Khalid, N. (2014). Enhancement of regeneration efficiency in banana (Musa acuminato cv. Berangan) by using proline and glutamine. Sci. Hortic. 2014,168, 33-37.

[87] Thomas, P., Swarna, G.K., Roy, P.K., and Patil, P. (2008b). Identification of culturable and originally non-culturable endophytic bacteria isolated from shoot tip cultures of banana cv. Grand Naine. Plant Cell Tissue Organ Cult. 2008b; 93, 55-63.

[88] Odutayo, O., Oso, R., Akinyemi, B., and Amusa, N. (2004). Microbial contaminants of cultured Hibiscus cannabinus and Telfaria occidentalis tissues. Afr. J. Biotechnol. 2004; 3, 473-476.

[89] Odutayo, O.I., Amusa, N.A., Okutade, O.O., and Ogunsanwo, Y. (2007). Sources of microbial contamination in tissue culture laboratories in southwestern Nigeria. Afr. J. Agric. Res. 2007; 2, 067 072.

[90] Omamor, I., Asemota, A., Eke, C., and Eziashi, E. (2007). Fungal contaminants of the oil palm tissue culture in Nigerian institute for oil palm research (NIFOR). Afr. J. Agric. Res. 2007; 2, 534-537.

[91] Msogoya, T., Kanyagha, H., Mutigitu, J., Kulebelwa, M., and Mamiro, D. (2012). Identification and management of microbial contaminants of banana in vitro cultures. J. Appl. Biosci. 2012; 55, 3987-3994.

[92] Helaly, M.N., El-Metwally, M.A., El-Hoseiny, H., Omar, S.A., and ElSheery, N.I. (2014). Effect of nanoparticles on biological contamination of 'in vitro'cultures and organogenic regeneration of banana. Aust. J. Crop Sci. 2014; 8, 612-624.

[93] Bradbury, J. (1987). Identification of cultivable bacteria from plants and plant tissue cultures by use of simple classical methods. Acta hortic. 1987; 225, 27 - 37.

[94] Obuekwe, C., and Osagie, I. (1989). Morphological changes in infected wilt-resistant and wilt-susceptible oil palm progenies and hydrolytic enzyme activities associated with the Fusarium oxysporum f. sp. elaeidis pathogens. Oléagineux (Paris) 1989; 44, 393-402.

[95] Ryan, R.P., Germaine, K., Franks, A., Ryan, D.J., and Dowling, D.N. (2008). Bacterial endophytes: recent developments and applications. FEMS Microbiol. Lett. 2008; 278, 1-9.

[96] Thomas, P., and Reddy, K.M. (2013). Microscopic elucidation of abundant endophytic bacteria colonizing the cell wall-plasma membrane peri-space in the shoot-tip tissue of banana. AoB Plants 2013; 5, plt011.

[97] Thomas, P., and Sekhar, A.C. (2014). Live cell imaging reveals extensive intracellular cytoplasmic colonization of banana by normally non-cultivable endophytic bacteria. AoB Plants 2014; 6, plu002.

[98] Tyler, H.L., and Triplett, E.W. (2008). Plants as a habitat for beneficial and/or human pathogenic bacteria. Annu. Rev. Phytopathol. 2008;46, 53-73.

[99] CIDES (1999). Micropropagation en entreprise - cahier de références techniques (CIDES) 1999.

[100]Anicker, B., Thomas, P., Janakiram, T., Venugopalan, R., and Narayanappa, S.B. (2007). Influence of cytokinin levels on in vitro propagation of shy suckering chrysanthemum "Arka Swarna" and activation of endophytic bacteria. In vitro Cell Dev Biol Plant. 2007, 43, 614-622.

[101]Thomas, P., Swarna, G.K., Patil, P., and Rawal, R.D. (2008a). Ubiquitous presence of normally non-culturable endophytic bacteria in field shoot-tips of banana and their gradual activation to quiescent cultivable form in tissue cultures. Plant Cell Tissue Organ Cult. 2008a; 93, 39-54.

[102]Dangi, M., Gill, M., and Saini, H. (2009). Factors affecting in vitro shoot regeneration in banana cv. Grand Naine. Indian J. Plant Physiol $2009 ; 14,39-43$

[103]Mng'omba, S.A., du Toit, E.S., Akinnifesi, F.K., and Venter, H.M. (2007). Effective preconditioning methods for in vitro propagation of Uapaca kirkiana Müell Arg. tree species. Afr. J. Biotechnol. 2007; 6 , 1670-1676.

[104] Azam, F.M.S., Islam, S., Rahmatullah M. and Zaman A. (2010). Clonal Propagation of Banana (Musa spp.) cultivar 'BARI-1' (AAA Genome, Sapientum Subgroup). Acta Hort, 2010; 537-544.

[105]Silué, O.; Kouassi, K M., Koffi, K E., Kouakou, K. E. P., and Aké, S. (2017). Effect of adenine sulphate, casein hydrolysate and spermidine on in vitro shoot multiplication of two banana varieties (FHIA-21 and PITA-3). Afr. J. Biotechnol. 2017; 16 (46), 2152-2159.

[106]Prabhath, G. P. W. A., and De Silva T. (2014). Micropropagation of M balbisiana and cultivated banana variety "Ambun", using immature male flowers. Asian J. Plant Sci. Res., 2014, 4 (4):54-61.

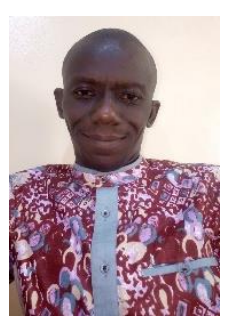

Eustache T. A-E F. Agbadje was born in 1970 in Segbohoue (Benin). After obtaining a Master's degree in Natural Sciences in 1995, he taught Life and Earth Sciences in various secondary schools. Since 2011, he began his initiation to research at the Department of Genetics and Biotechnology/ Faculty of Sciences and Techniques at the same University. He obtained a master's degree in Genetics, Biotechnologies and Biological Resources in 2013. He is currently a PhD student in crops biotechnologies and plant breeding.

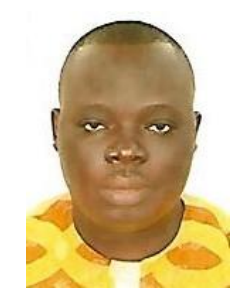

Arnaud Agbidinoukoun is senior lecturer and researcher at the Central Laboratory of Plant Biotechnology and Plant Improvement, Department of Genetics and Biotechnology, Faculty of Sciences and Techniques/ University of Abomey-Calavi, Republic of Benin. He has started with plant Biotechnology research since 2007. His long-term goal is to conduct basic and applied research in production of free-disease plant material and safeguard plant genetic resources using tissue culture and cryopreservation tools for fighting hunger in Benin and those in sub-Sahara Africa. 